\title{
REKAM JEJAK DAN POTENSI PENELITIAN DI BADAN USAHA MILIK DESA : STUDI BIBLIOMETRIK PUBLIKASI TAHUN 2015-2020
}

\section{(TRACK RECORD AND POTENTIAL RESEARCH IN VILLAGE OWNED ENTERPRICE: BIBLIOMETRIC STUDY ON PUBLICATIONS 2015-2020)}

\author{
Andre Kusuma \\ andrekusuma571@gmail.com \\ Universitas Jember \\ Hendrawan Santosa Putra \\ hendrawan@unej.ac.id \\ Universitas Jember \\ Sudarno ${ }^{3}$ \\ sudarno@unej.ac.id \\ Universitas Jember
}

\begin{abstract}
The development of BUMDes in Indonesia occurred after the issuance of Law No. 4 of 2015. This development is not only judged by the units formed but the number of studies as well. The development of BUMDes research has occurred significantly, this brings new needs so that these developments can be communicated. Bibliometrics are used to communicate the development of a discipline for further research needs. This study aims to map the development of research related to BUMDes from 2015-2020. The summary of this research is expected to be the starting point for further research in BUMDes studies. The research method used is quasi qualitative with bibliometric analysis. The research data is in the form of articles collected from the crossref meta data from 2015-2020. Filtering articles using the keywords "bumdes" and "village owned enterprises" and journals must be indexed on SINTA or SCOPUS. The results of this study indicate that of the 223 articles collected, 105 articles have been indexed in SINTA and 2 research articles have been indexed by SCOPUS. Trends in accounting research topics (2015-2020) are finance and management, and the potential for further research is related to the study of effective governance for BUMDes.
\end{abstract}

Keywords: Bibliometric; BUMDes; Research Opportunities; Research Trends; SINTA

\begin{abstract}
ABSTRAK
Perkembangan BUMDes di Indonesia terjadi setelah dikeluarkannya UU No. 4 Tahun 2015. Perkembangan ini bukan hanya dinilai dari unit yang terbentuk melainkan jumlah penelitian juga. Perkembangan penelitian BUMDes terjadi secara signifikan, hal ini membawa kebutuhan baru agar perkembangan tersebut dapat dikomunikasikan. Bibliometrik digunakan untuk mengkomunikasikan perkembangan suatu disiplin ilmu untuk kebutuhan penelitian selanjutnya. Penelitian ini bertujuan untuk memetakan perkembangan penelitian terkait dengan BUMDes dari tahun 2015-2020. Rangkuman penlitian ini diharapkan dapat menjadi pijakan awal untuk penelitian selanjutnya dalam kajian BUMDes. Metode penelitian yang digunakan yaitu kuasi kualitatif dengan analisis bibliometrik. Data penelitian berupa artikel yang dikumpulkan dari meta data Crossref dalam kurun waktu 2015-2020. Penyaringan artikel menggunakan keyword "bumdes" dan "village owned enterprice" serta jurnal harus terindeks
\end{abstract}


di SINTA atau SCOPUS. Hasil dari penelitian ini menunjukan dari 223 artikel yang dikumpulkan terdapat 105 artikel yang sudah terindeks di SINTA dan 2 artikel penelitian terindeks SCOPUS. Tren topik penelitian akuntansi (20152020) adalah keuangan dan manajemen, dan potensi penelitian selanjutnya terkait dengan kajian tata kelola yang efektif untuk BUMDes

Kata kunci : Bibliometrik; BUMDes; Peluang Riset; SINTA; Tren Penelitian

\section{PENDAHULUAN}

Pengesahan Undang-Undang Nomor 32 Tahun 2004 tentang Pemerintahan Daerah memberikan wewenang penuh kepada pemeritah daerah untuk mengatur dan mengurus pemerintahannya sendiri, kecuali yang menjadi kewenangan pemerintah pusat sesuai dengan undang-undang yang berlaku. Kewenangan tersebut selanjutnya disebut sebagai otonomi daerah. Pelaksanaan otonomi daerah bahkan sampai pada tingkat pemerintahan terkecil yaitu desa yang tertuang dalam Undang-Undang Nomor 6 Tahun 2014 tentang Desa, dalam undang-undang tersebut juga disebutkan bahwa desa adalah kesatuan masyarakat hukum yang memiliki batas wilayah yang berwenang untuk mengatur dan mengurus urusan pemerintahan berdasarkan prakarsa masyarakat, hak asal usul, dan/atau hak tradisional yang diakui dan dihormati dalam sistem pemerintahan Negara Kesatuan Republik Indonesia. Pengertian desa diatas dapat dimaknai bahwa otonomi di tingkat desa bukan semata mata penyerahan wewenang dari pemerintah melainkan kewenangan istimewa yang dimiliki oleh desa berdasarkan asal-usul dan adat istiadatnya dengan tanggungjawab yang pasti terhadap pemerintah (Maulana, 2014).

Partisipasi masyarakat bisa diwujudkan dengan adanya Badan Permusyawaratan Desa (BPD) dalam pemerintahan desa yang berperan aktif untuk menggiring arah pembangunan desa berdasarkan potensi yang dimilki. Wujud nyata dari kolaborasi atas partisipasi masyarakat dan pemerintah desa adalah dengan pendirian BUMDes sebagai wadah untuk mengelolah potensi dari desa. Sejak tahun 2004 tertuang dalam Undang-Undang Nomor 32 Tahun 2004 Pasal 213 ayat (1)"Desa dapat mendirikan badan usaha milik desa sesuai dengan kebutuhan dan potensi desa yang berepedoman pada peraturan perudang-undangan". Badan Usaha Milik Desa yang selanjutnya disebut BUMDes menurut Undang-Undang Nomor 6 Tahun 2014 merupakan badan usaha yang seluruh atau sebagian besar modalnya dimiliki oleh desa melalui penyertaan secara langsung yang berasal dari kekayaan desa yang dipisahkan guna mengelola aset, jasa pelayanan, dan usaha lainnya untuk sebesar-besarnya kesejahteraan masyarakat desa. Akan tetapi belum adanya peraturan yang spesifik tentang keberadaan BUMDes membuat keberadaannya kurang dilirik sebagai alternatif usaha mandiri desa yang menjanjikan. Hal ini disambut dengan dikeluarnya Peraturan Menteri Desa, Pembangunan Daerah Tertinggal dan Transmigrasi Republik Indonesia Nomor 4 Tahun 2015 tentang pendirian, pengurusan dan pengelolahan, dan pembubaran BUMDes sehingga menjadi semakin jelas keberadaan sebagai lembaga hukum resmi melalui peraturan desa dalam pembentukannya dan menjadi pijakan untuk mendongkrak pendapatan asli desa melalui usaha mandiri.

Tabel 1. Jumlah Unit BUMDes tahun 2015-2019 di Indonesia

\begin{tabular}{cc}
\hline Tahun & Jumlah Unit BUMDes \\
\hline 2015 & 1.022 Unit \\
\hline 2016 & 11.945 Unit \\
\hline 2017 & 39.149 Unit \\
\hline 2018 & 45.549 Unit \\
\hline 2019 & 50.199 Unit
\end{tabular}

Sumber: Menteri Desa, Pembangunan Daerah Tertinggal dan Transmigrasi (Mendes PDTT) 
Dengan demikian berkembang juga penelitian terkait dengan BUMDes sebagai upaya peningkatan nilai BUMDes di desa, yang tersaji dalam berbagai bahasan dan metode yang berbeda. Dalam berbagai kasus penelitian terkait BUMDes masih berfokus pada sistem administrasi, pertanggungjawaban, peningkatan kinerja, pelatihan, dan strategi pengembangan. Penelitian tersebut diharapkan dapat memilki kontribusi baik secara langsung maupun tidak langsung kepada BUMDes dalam pengelolahannya.

Peningkatan penelitian ini perlu adanya komunikasi yang jelas terkait dengan tren riset yang terjadi dengan pemetaan penelitian, sehingga topik bahasan yang sudah jenuh diteliti tidak terulang dan perkembangan penelitian lebih signifikan. Bibliometrik kerap digunakan untuk memetakan perkembangan penelitian pada berbagai disiplin ilmu. Penggunaan analisis bibliometrik pada penelitian diranah BUMDes belum pernah dilakukan, sehingga tidak terdapat gambaran tren penelitian yang terjadi meskipun secara real terjadi perkembangan. Hal tersebut memperkuat latar belakang penelitian ini untuk dilakukan, sebagai fasilitas awal para peneliti yang tertarik dengan topik ini untuk mampu mengidentifikasi tren, topik, dan metode yang kerap digunakan. Analisis bibliometrik digunakan untuk memetakan penelitian di ranah BUMDes pada penelitian ini, dan penerbitan Peraturan Menteri Desa Pembangunan Daerah Tertinggal dan Transmigrasi Republik Indonesia Nomor 4 Tahun 2015 menjadi latar belakang pemilihan tahun awal, sehingga rentang waktu pemetaan penelitian bumdes dimulai dari 2015 sampai dengan 2020. Oleh karena itu penelitian ini diharapkan membantu para peneliti selanjutnya yang mempunyai ketertarikan dalam bidang bumdes untuk dapat mengetahui topik apa yang sudah diteliti dan belum diteliti, trend metode penelitian yang banyak digunakan dalam penelitian ini, serta topik yang sedang tren diteliti atau sudah jenuh diteliti. Sehingga, hasil penelitian ini dapat menjadi rujukan dan pijakan awal untuk mengkaji penelitian terkait dengan BUMDes.

\section{TINJAUAN LITERATUR BUMDes}

Badan Usaha Milik Desa yang selanjutnya disebut BUMDes menurut Undang-Undang Nomor 6 Tahun 2014 merupakan badan usaha yang seluruh atau sebagian besar modalnya dimiliki oleh desa melalui penyertaan secara langsung yang berasal dari kekayaan desa yang dipisahkan guna mengelola aset, jasa pelayanan, dan usaha lainnya untuk sebesar-besarnya kesejahteraan masyarakat desa. Pembentukan melalui badan permusyawatan desa dan disahkan dengan peraturan desa untuk mengoptimalkan potensi desa, menjadikan BUMDes sebagai indikator penting untuk mendongkrak perekonomian desa. Peraturan Menteri Desa Nomor 4 Tahun 2015 juga menegaskan bahwa pendirian bumdes dimaksutkan sebagai fasilitas penampung segala aktifitas ekonomi dan pelayanan umum di desa. BUMDes memiliki tujuan untuk meningkatakan perekonomian desa dan kesejahteraan masyarakat dengan cara meningkatan pendapatan asli desa. Pendirian BUMDes dilakukan melalui musyawarah desa dengan mempertimbangkan inisiatif pemerintah dan masayarakat desa, potensi usaha ekonomi desa, sumber daya yang tersedia, pengelolah dan sumber modal yang akan digunakan.Pendirian dan pengelolaan BUMDes merupakan perwujudan dari produktifitas ekonomi desa yang dilakukan berdasarkan beberapa prinsip yaitu emansipatif, partisipatif, kooperatif, transparasi, akuntabel, dan secara keberlanjutan (Ridlwan, 2015c).

\section{Bibliometrik}

Bibliometrik dapat diartikan sebagai serangkaian tindakan kuantitatif yang bertujuan untuk menilai dampak dan luaran penelitian yang selanjutnya disebut bibliometrik (Purnomo, 2019). Berasal dari kata biblio yang berarti buku dan metrics yang berarti mengukur, bibliometrik juga bisa diartikan sebagai suatu kajian pengukuran perkembangan literatur. Definisi menurut prosesnya dapat dikatakan bahwa bibliometrik adalah kajian yang 
mengukur perkembangan penelitian, literatur, buku atau dokumen pada bidang tertentu baik secara kuantitatif atau kualitatif dengan menggunakan metode statistika (Hakim, 2020).

Sedangkan pendapat lain mengatakan bibliometrik sebagai kajian analisis bibliografi pada kegiatan ilmiah, yang beranggapan bahwa seorang peneliti melakukan penelitiannya dan harus mengkomunikasikan hasilnya pada teman sejawat (Tupan \& Rachmawati, 2018). Sehingga bisa dikatakan bahwa dengan melakukan analisis bibliometrik bisa menjadi media komunikasi dari hasil penelitian penelitian yang lalu. Hal tersebut didukung dengan pendapat bahwa bibliometrik dapat memberikan gambaran secara makro secara historis sebuah publikasi ilmiah dalam suatu bidang penelitian yang spesifik (Rachmawati et al., 2020). Sehingga dapat disimpulkan bahwa bibliometrik adalah kajian yang mengukur perkembangan dari kegiatan ilmiah melalui literatur secara kuantitatif maupun kualitatif untuk menilai dampak dan hasil penelitian untuk kepentingan penelitian yang lebih efektif di masa depan.

\section{Analisis Co-word}

Analisis Co-word dilakukan berdasarkan anggapan bahwa kata kunci artikel merupakan deskripsi yang memadai untuk representasi isi dari muatan artikel tersebut. Teknik ini menggambarkan hubungan antara kata kunci dengan membangun beberapa jaringan yang menyoroti hubungan antara kata kunci, dan dimana hubungan antara jaringan yang mungkin terjadi. Analisis Co-word bertujuan untuk menganalisis isi, pola, dan kecenderungan (trend) dari kumpulan suatu dokumen dengan mengukur hubungan kekuatan kata kuncinya. Analisis co-words juga digunakan untuk pengelompokan dokumen dan mengidentifikasi gugus dokumen yang memiliki persamaan topik. Menurut (Basuki, 2002) "pemetaan berbasis coword merupakan pemetaan berbasis frekuensi kata yang muncul dalam dokumen (atau judul dan/ atau abstraknya)". Semakin banyak munculnya kata kunci yang sama dalam suatu klompok artikel yang telah ditentukan, maka semakin erat juga hubungan antara artikel tersebut. Sehingga intensitas kata kunci yang muncul dapat kita gunakan untuk menilai seberapa penting bidang tertentu untuk dimunculkan dalam pemetaan. Hasil dari metode ini dapat digunakan untuk memetakan tren dan perkembangan dari suatu topik penelitian yang sedang terjadi (Farida \& Firmansyah, 2020a).

\section{Analisis Subjek}

Analisis subjek (content analysis) merupakan metode pengumpulan data penelitian melalui teknik observasi dan analisis terhadap isi atau pesan dari suatu dokumen (Indriantoro, 2016a). Metode ini digunakan untuk mengidentifikasi karakteristik dari dokumen yang ditelaah, sehingga menghasilkan penjelasan secara objektif dan sistematik terkait dengan objek yang diteliti . Maka secara umum analisis isi kuantitatif adalah teknik penelitian ilmiah yang ditujukan untuk mengetahui gambaran karakteristik isi dan menarik inferensi dari isi.

Analisis isi ditujukan untuk mengidentifikasi secara sistematis komunikasi yang tampak (manifest), dan dilakukan secara objektif, valid, reliabel dan dapat direplikasi. Sehingga hasil dari analisis ini dapat berupa pengkategorian isi, pemberian kode berdasarkan karakteristik yang ada di dalam dokumen atau kejadian yang menjadi objek penelitian.

\section{METODE PENELITIAN}

Pendekatan penelitian yang digunakan adalah kuasi kualitatif. Pendekatan penelitian ini merupakan salah satu desain dari paradigma postpositivism. Pendekatan kuasi kualitatif merupakan penelitian dimana penggunaan teori masih dimungkinkan sebagai alat penelitian sejak peneliti menemukan masalah, kemudian mengumpulkan data, sampai pada menganalisis data. Studi Bibliometrik digunakan dalam penelitian ini untuk mengukur perkembangan penelitian dengan memanfaatkan informasi bibliografi yang terdapat dalam artikel penelitian. Jenis data yang digunakan dalam penelitian ini merupakan data dokumenter berupa artikel ilmiah dan sumber data yang digunakan dalam penelitian ini yaitu data sekunder. Pengumpulan data 
sekunder berupa artikel dilakukan dengan menggunakan software Harzing's Publish or Perish V.7.25 sebagai media pencarian artikel dengan title words "Bumdes" dan "Village Owned Enterprice". Rentang waktu ditetapkan sebagai batasan publikasi dalam penelitian ini adalah dari tahun 2015-2020. Kriteria selanjutnya ditetapkan untuk jurnal penelitian yang sudah terindeks SINTA atau SCOPUS. Analisis subyek dan analisis co-word digunakan dalam penelitian ini untuk pengkategorisasian artikel yang dianalisis dan digunakan untuk memetakan perkembangan penelitian BUMDes. Pengelompokan artikel ini berdasarkan pada klasifikasi metode penelitian yang telah dipaparkan oleh (Indriantoro, 2016b) dan pengelompokan topik akuntansi oleh (Coyne et al., 2010a).

Tabel 2. Kriteria pengumpulan artikel

\begin{tabular}{ccc}
\hline No & Kriteria & Keterangan \\
\hline 1 & Title words & BUMDes ; Village Owned Enterprice \\
\hline 2 & Keyword & BUMDes \\
\hline 3 & Tahun Publikasi & $2015-2020$ \\
\hline 4 & Jurnal & Terindeks SINTA atau SCOPUS \\
\hline
\end{tabular}

\section{HASIL DAN PEMBAHASAN}

\section{Jumlah artikel BUMDes terpublikasi dari tahun 2015 - 2020}

Berdasarkan hasil pencarian dengan menggunakan bantuan software Harzing's Publish or Perish V.7.25 menggunakan kata kunci "bumdes" dan "Village Owned Enterprice", serta penambahan keywords "bumdes" dalam pencarian ini menghasilkan beberapa artikel terkait dengan BUMDes. Pengambilan data dari Crossref dengan rentang waktu 2015 - 2020 terkait dengan publikasi artikel BUMDes. Dari hasil pencarian melalui Harzing's Publish or Perish V.7.25 didapatkan 166 artikel berbahasa Indonesia dan 57 artikel berbahasa Inggris.

Tabel 3. Hasil pencarian artikel melalui Harzing's Publish or Perish V.7.25

\begin{tabular}{cccc}
\hline \multicolumn{2}{c}{ Bahasa Indonesia } & \multicolumn{2}{c}{ Bahasa Inggris } \\
\hline Tahun & Jumlah Artikel & Tahun & Jumlah Artikel \\
\hline 2015 & 3 & 2015 & - \\
\hline 2016 & 2 & 2016 & - \\
\hline 2017 & 10 & 2017 & 1 \\
\hline 2018 & 24 & 2018 & 8 \\
\hline 2019 & 70 & 2019 & 20 \\
\hline 2020 & 57 & 2020 & 57 \\
\hline Total & 166 & Total & \\
\hline \multicolumn{2}{r}{ Sumber : Data Sekunder dari Harzing's Publish or Perish V.7.25 }
\end{tabular}

Peningkatan artikel penelitian tersebut tergambar pada Tabel 4 pada tahun 2015 sampai dengan 2020. Perkembangan publikasi artikel penelitian BUMDes tertinggi terjadi pada tahun 2019, mencapai 90 artikel (40\%). Awal penelitian BUMDes mulai banyak dikaji dari tahun 2017 dengan kenaikan artikel penelitian sebesar 4\%. Kenaikan paling besar terjadi pada tahun 2019 yang meningkat sebesar 26\% dari tahun sebelumnya, peningkatan ini bahkan hampir tiga kali lipat setiap tahunnya dari tahun 2017 sampai dengan 2019.

Tabel 4. Jumlah publikasi artikel BUMDes dari tahun 2015 - 2020

\begin{tabular}{ccc}
\hline Tahun & Jumlah Artikel & Persentase \\
\hline 2015 & 3 & $1 \%$ \\
\hline 2016 & 2 & $1 \%$ \\
\hline 2017 & 11 & $5 \%$ \\
\hline 2018 & 32 & $14 \%$ \\
\hline 2019 & 90 & $40 \%$ \\
\hline 2020 & 85 & $38 \%$ \\
\hline Jumlah & $\mathbf{2 2 3}$ & $\mathbf{1 0 0 \%}$ \\
\hline
\end{tabular}

Sumber : Data Sekunder dari Harzing's Publish or Perish V.7.25 
Pertumbuhan dari jumlah publikasi yang terjadi merupakan dampak tidak langsung atas peraturan yang telah berlaku. Undang - Undang No 4 Tahun 2015 membawa dampak sangat positif dalam kemajuan dan keberhasilan pembentukan BUMDes di berbagai wilayah. Hal ini menjadi perhatian baru bagi para peneliti untuk ikut andil dalam keberhasilan ini. Dengan cara melakukan penelitian terkait dengan BUMDes yang memberikan dampak secara tidak langsung bagi kemajuan BUMDes. Pencapaian pemerintah ini layak untuk memiliki dukungan dengan berbagai kajian penelitian yang dilakukan oleh para peneliti. Menjadi titik awal pertumbuhan penelitian, tahun 2015 dan 2016 bisa dikatakan sebagai proses identifikasi apakah topik pada penelitian BUMDes merupakan topik yang menarik. Hal ini sekali lagi juga berkaitan dengan pertumbuhan BUMDes yang masih belum signifikan pada dua tahun tersebut. Sampai pada tahun 2017 sampai sekarang menjadi masa emas untuk BUMDes menjadi wadah kajian ilmiah yang sangat menarik untuk peneliti gali.

\section{Jumlah artikel dari jurnal terindeks SINTA dan SCOPUS tahun 2015 - 2020}

Hasil sajian perkembangan publikasi artikel BUMDes tahun 2015 - 2020 pada Tabel 4 merupakan hasil dari semua publikasi dari meta data Crossref. Sebanyak 223 artikel yang telah dipublikasi tidak semua diterbitkan oleh jurnal terindeks SINTA maupun SCOPUS . Pada Tabel 5 menunjukan jumlah artikel dari jurnal terindeks SINTA mulai dari S1 sampai dengan S6, dan Tabel 6 menunjukkan bagian dari 223 publikasi artikel dari jurnal yang terindeks di SCOPUS sebagai artikel berkualitas internasional.

Tabel 5. Jumlah artikel dari jurnal terindeks SINTA

\begin{tabular}{ccccccc}
\hline SINTA & 2015 & 2016 & 2017 & 2018 & 2019 & 2020 \\
\hline S1 & 0 & 0 & 0 & 0 & 0 & 0 \\
\hline S2 & 2 & 0 & 4 & 5 & 2 & 4 \\
\hline S3 & 0 & 0 & 2 & 4 & 5 & 8 \\
\hline S4 & 0 & 1 & 0 & 6 & 19 & 6 \\
\hline S5 & 0 & 0 & 2 & 5 & 12 & 14 \\
\hline S6 & 0 & 0 & 0 & 3 & 1 & 0 \\
\hline Sub Total & 2 & 1 & 8 & 23 & 40 & 33 \\
\hline Total & \multicolumn{7}{c}{105} \\
\hline \multicolumn{7}{c}{ Sumber : Data diolah, 2020}
\end{tabular}

Berdasarkan hasil temuan sebanyak 105 artikel dari 223 artikel hasil pencarian merupakan artikel yang diterbitkan jurnal terindeks SINTA. Pada tahun 2015 tercatat 2 artikel terindeks SINTA pada jurnal FIAT JUSTISIA dengan topik BUMDes dengan golongan S2. Artikel penelitian yang ditulis oleh (Ridlwan, 2015a) menjadi pembahasan pertama penguatan BUMDes sebagai lembaga ekonomi desa yang mempunyai landasan hukum yang kuat. Fokus penelitiannya untuk membangun citra bahwa BUMDes bukan hanya sekedar lembaga khas desa tanpa peraturan jelas. Kejelasam peraturan terkait BUMDes dijabarkan secara historis sehingga dapat dikonfirmasi bahwa kejelasan hukum BUMDes dapat secara jelas diketahui. Menariknya penelitian yang dilakukan oleh (Ridlwan, 2015c) berkesan melanjutkan penelitian sebelumnya dengan bahasan betapa pentingnya kehadiran BUMDes untuk mendorong perekonomian desa secara mandiri. Penelitian ini lah yang menjadi pemicu kesadaran bahwa urgensi bumdes dalam perekonomian desa menjadi pilar penting.

Berawal dari tahun 2015 para peneliti menilai perlu menguatkan pentingnya BUMDes terlebih dahulu sehingga penelitian berfokus pada fondasi dari pembentukan BUMDes. Tahun setelahnya pola berganti untuk menata bagaimana seharusnya pengelolahan BUMDes dijalankan agar lebih efektif dan efisien dalam kegiatan operasionalnya. Pergantian selanjutnya karena dianggap bahwa beberapa tahun terakhir sudah cukup untuk menata secara baik bagaimana pengelolahan seharusnya berjalan, tren penelitian berfokus pada 
evaluasi dari pengelolahan yang sudah dijalankan. Pola tren penelitian ini dapat menggambarkan bagaimana peran para peneliti sebagai pendamping dari perkembangan bumdes secara tidak langsung. Peneliti berperan sebagai pengamat pada tahun 2015, tergambar pada penelitian (Ridlwan, 2015a) berkaitan tentang landasan hukum dan pentingnya kehadiran BUMDes dalam perekonomian desa. Pergantian peran selanjutnya pada tahun 2017 menjadi penuntun kegiatan BUMDes tergambar pada penelitian (Sufi \& Saputra, 2017) terkait program pemberdayaan desa untuk pembentukan BUMDes, (Surono, 2017) terkait konsep pengelolahan bumdes untuk peningkatan kesejahteraan masayarakat, atau penelitian yang dilakukan oleh (Zulyanto et al., 2017) terkait penerapan konsep pembiayaan dalam kegiatan operasional BUMDes. Beberapa penelitian tersebut menggambarkan peran peneliti sebagai penuntun untuk kegiatan BUMDes berjalan. Peran penelitian berganti menjadi pengawas dan evaluator BUMDes pada tahun 2018, hal tersebut tergambar pada penelitian yang dilakukan berfokus pada peran BUMDes secara nyata terhadap kegiatan ekonomi desa.

Pola penelitian yang sudah terjadi menimbulkan pemikiran bahwa peran peneliti pada tahun berikutnya akan menjadi pihak yang secara aktif melakukan rekomendasi atas evaluasi dan pengembangan yang telah dilakukan. Pemikiran tersebut terbukti oleh tren bahasan penelitian yang terjadi pada tahun 2019 dan 2020. Terdapat 73 artikel penelitian terideks SINTA dengan predikat S2 - S6 dengan fokus bahasan berkaitan dengan implementasi konsep pengelolahan BUMDes, evaluasi, dan rekomendasi strategi pengembangan dari masing masing BUMDes yang diteliti . Penelitian yang dilakukan oleh (Erlina \& Sirojuzilam, 2020a) berkaitan dengan penilaian efektifitas penerapan sistem pelaporan BUMDes, (Utama et al., 2019) evaluasi penerapan sistem operasional berbasis website di BUMDes, (Pradesa \& Agustina, 2020) implementasi konsep tanggungjawab sosial dalam pelaksanaan operasional BUMDes, (Rika Fatimah, 2019) implementasi model tentraprenuer dalam operasional BUMDes, dan (Sulaksana \& Nuryanti, 2019) pengembangan usaha BUMDes dalam skema studi kasus. Beberapa contoh diatas adalah sedikit dari gambaran bagaimana fokus penelitian pada 2 tahun terakhir berkaitan dengan pengembangan BUMDes dan evaluasi terhadap pengelolahan yang sudah berjalan sebelumnya.

Berdasarkan hasil dari temuan peneliti, masih sedikit artikel penelitian yang diterbitkan oleh jurnal yang terindeks di SCOPUS. Dapat dilihat pada Tabel 6 artikel penelitian terkait BUMDes yang terindeks SCOPUS berasal dari Jurnal Studi Pemuda dar Universitas Gadjah Mada dan Journal of Advanced Research in Dynamical and Control Systems dari

Tabel 6. Jumlah artikel dari jurnal terindeks SCOPUS

\begin{tabular}{cc}
\hline Indeks Scopus & Jumlah Artikel \\
\hline Q1 & - \\
\hline Q2 & 1 \\
\hline Q3 & 1 \\
\hline Q4 & - \\
\hline Jumlah & 2 \\
\hline \multicolumn{2}{c}{ Sumber : Data diolah, 2020 }
\end{tabular}

\section{Kontribusi Penulis, Jurnal dan Intitusi pada artikel penelitian BUMDes}

Produktifitas para peneliti terkait dengan BUMDes dari 105 artikel jurnal yang terindeks di SINTA maupun SCOPUS tidak menunjukkan adanya penulis dengan kontribusi yang signifikan dari jumlah hasil tulisannya. Kontribusi penelitian BUMDes terbanyak salah satunya ditulis oleh Ulul Hidayah dkk, sebanyak 3 artikel terpublikasi SINTA, serta kontribusi lain sebanyak 2 artikel oleh Zulkarmain Ridlwan dengan 2 artikel terpublikasi dan terimdeks SINTA pada tahun 2015. Sesuai dengan Tabel 7 untuk penulis selain pada tabel sisanya masing masing penulis memiliki satu artikel penelitian terkait dengan BUMDes. 
Tabel 7. Kontribusi penulis dalam penelitian BUMDes

\begin{tabular}{ll}
\hline \multicolumn{1}{c}{ Penulis } & Jumlah Artikel \\
\hline Amrina Rosyada & 3 \\
\hline Ulul Hidayah & 3 \\
\hline Sri Mulatsih & 3 \\
\hline Yeti Lis Purnamadewi & 3 \\
\hline Vembri Aulia Rahmi & 2 \\
\hline Muhammad Zainudin Fathoni & 2 \\
\hline Aprina Nugrahesthy Sulistya Hapsari & 2 \\
\hline Iyus Akhmad Haris & 2 \\
\hline Hadi Ismanto & 2 \\
\hline Jumaiyah & 2 \\
\hline Yulinda Devi Pramita & 2 \\
\hline Vina Anggilia Puspita & 2 \\
\hline Sri Wahyuni $\quad$ Sumber : Data diolah, 2020
\end{tabular}

Berdasarkan hasil analisis yang tergambar pada Tabel 8 produktivitas jurnal yang menerbitkan penelitian topik BUMDes terbanyak terdapat pada Jurnal Ilmiah Akuntansi dan Humanika dengan total 4 artikel terpublikasi dan terindeks SINTA (S5) pada tahun 2019. Community Empowerment menjadi jurnal terproduktif kedua yang mempublikasikan penelitian BUMDes dengan 3 artikel penelitian bersama dengan Jurnal Comvice. Selanjutnya Jurnal FIAT JUSTISIA menjadi jurnal terproduktif ketiga bersama 5 jurnal lainnya dengan publikasi artikel penelitian berjumlah 2 artikel dan jurnal lain mempublikasikan artikel penelitian BUMDes masing-masing 1 per jurnal.

Tabel 8. Produktivitas jurnal penelitian BUMDes

\begin{tabular}{lc}
\hline \multicolumn{1}{c}{ Jurnal } & Jumlah Artikel \\
\hline Jurnal Ilmiah Akuntansi dan Humanika & 4 \\
\hline Community Empowerment & 3 \\
\hline Comvice : Journal of community service & 3 \\
\hline Dinamisia : Jurnal Pengabdian Kepada Masyarakat & 3 \\
\hline FIAT JUSTISIA:Jurnal Ilmu Hukum & 2 \\
\hline Jurnal Pendidikan Ekonomi Undiksha & 2 \\
\hline Jurnal Pengabdian Masyarakat Universitas Merdeka Malang & 2 \\
\hline RESONA : Jurnal Ilmiah Pengabdian Masyarakat & 2 \\
\hline Wikrama Parahita : Jurnal Pengabdian Masyarakat & 2 \\
\hline
\end{tabular}

Sumber : Data diolah, 2020

Pada level institusi berdasarkan hasil analsis sesuai dengan Tabel 9 menunjukan bahwa Universitas Pendidikan Ganesha merupakan lembaga yang paling banyak mempublikasi penelitian terkait dengan BUMDes. Universitas Muhammadiyah Magelang dengan publikasi artikel penelitian BUMDes sebanyak 4 artikel menjadi urutan kedua sebagai lembaga produktif dalam penelitian ini. Selain Universitas Udayana dan Universitas Merdeka Malang dengan publikasi 3 artikel penelitian terkait dengan BUMDes, lembaga lain mempublikasikan 2 artikel penelitian BUMDes dan paling sedikit 1 artikel untuk lembaga sisanya. 
Tabel 9. Kontribusi institusi dalam penelitian BUMDes

\begin{tabular}{lc}
\hline \multicolumn{1}{c}{ Institusi } & Jumlah Artikel \\
\hline Universitas Pendidikan Ganesha & 9 \\
\hline Universitas Muhammadiyah Magelang & 4 \\
\hline Universitas Serang Raya & 4 \\
\hline Universitas Lancang Kuning & 3 \\
\hline Universitas Merdeka Malang & 3 \\
\hline Universitas Udayana & 3 \\
\hline Universitas 17 Agustus 1945 Surabaya & 2 \\
\hline Universitas Airlangga & 2 \\
\hline Universitas Muhammadiyah Gresik & 2 \\
\hline Universitas Muhammadiyah Mataram & 2 \\
\hline Universitas Muhammadiyah Palopo & 2 \\
\hline Universitas Muhammadiyah Yogyakarta & 2 \\
\hline Universitas Padjadjaran & 2 \\
\hline \multicolumn{2}{c}{ Sumber : Data diolah 2020}
\end{tabular}

Sumber : Data diolah, 2020

\section{Pemetaan tren penelitian BUMDes dari tahun 2015-2020}

Analisis co-words merupakan salah satu cara untuk memahami dinamika ilmu pengetahuan, karena didasarkan pada asumsi bahwa kata kunci suatu artikel merupakan deskripsi yang dapat dijadikan representasi isi dari muatannya (Farida \& Firmansyah, 2020b). Hasil dari analisis co-word ditemukan hasil sebanyak 109 kata kunci dalam penelitian BUMDes. Menggunakan minimum keterkaitan 3 menghasilkan 13 kata kunci yang terbagi menjadi 4 Kluster. Hasil dari keterkaitan kata kunci berdasarkan olahan dari VOS Viewer, antara lain: badan usaha milik desa (BUMDes) (59), desa (20), masyarakat desa (15), ekonomi desa (13), tata kelola (7), akuntabilitas (6), analisis swot (6), kesejahteraan (6), laporan keuangan (6), potensi desa (6), strategi pengembangan (6), village goverment (5), community empowerment (3). Secara keseluruhan kata kunci dalam penelitian bisa dilihat pada Gambar 1 yang dianalisis melalui VOS Viewer.

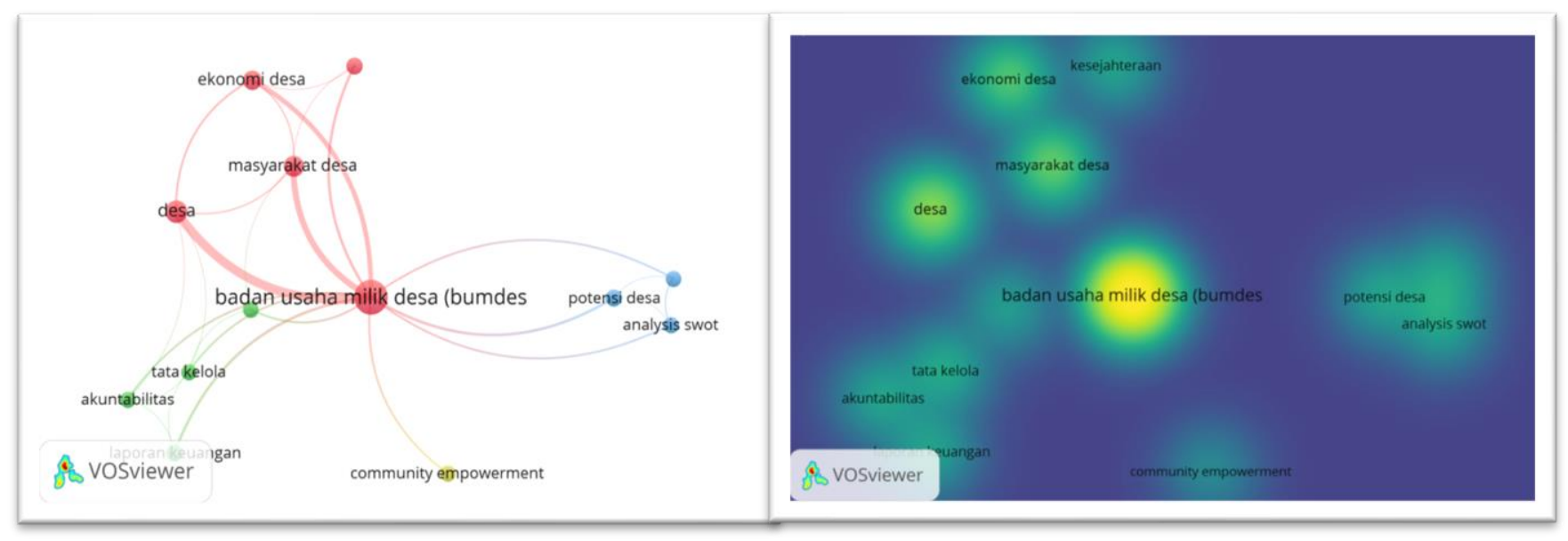

\section{Gambar 1. Pemetaan keyword penelitian BUMDes \& Visualisasi Density kata kunci penelitian BUMDes}

Hasil dari analisis ini dapat digunakan sebagai gambaran umum dan tren topik penelitian yang banyak dilakukan mulai dari 2015-2020. Pada Gambar 1 semakin sering kata kunci itu digunakan maka semakin besar juga tampilan lingkaran pada hasil analisisnya. Garis-garis penghubung antara kata kunci mengambarkan seberapa sering kata kunci tersebut digunakan bersama dalam sebuah publikasi. Semakin tebal dan banyak garis, maka kata 
kunci-kata kunci tersebut semakin sering muncul dalam publikasi. Visualisasi Density pada hasil olahan VOS Viewer menggambarkan titik warna setiap kata kunci dalam artikel berdasarkan kepadatan jumlah item yang terkait dengan item lain. Pada Gambar 1 juga dapat dilihat semakin jelas warna kuning yang dihasilkan, maka bahasan dengan kata kunci tersebut semakin sering untuk dibahas.

Secara lebih spesifik lagi pemetaan kata kunci dibagi berdasarkan beberapa cluster. Pengelompokan berdasarkan cluster digunakan untuk menemukan hubungan antar keterkaitan kata kunci dalam artikel penelitian (Farida \& Firmansyah, 2020b). Rincian dari Kluster kata kunci dalam penelitian BUMDes dapat dilihat pada Tabel 10 sebagai berikut:

Tabel 10. Rincian Kluster hasil analsis co-word

\begin{tabular}{cl}
\hline & \multicolumn{1}{c}{ Distribusi Kluster Kata Kunci } \\
\hline Kluster 1 & BUMDes, Desa, Ekonomi Desa, Kesejahteraan, Masyarakat Desa \\
\hline Kluster 2 & Akuntabilitas, Laporan Keuangan, Tata Kelola, Village Goverment \\
\hline Kluster 3 & Analisis SWOT, Potensi Desa, Strategi Pengembangan \\
\hline Kluster 4 & Community Empowerment \\
\hline
\end{tabular}

\section{a. Kluster 1}

Kata kunci pada kluster 1 terdiri dari 5 kata kunci yaitu BUMDes, Desa, Ekonomi Desa, Kesejahteraan, Masyarakat Desa. Kumpulan kata kunci ini mengindikasikan publikasi terkait dengan BUMDes yang berfokus pada peran keberadaan BUMDes untuk peningkatan ekonomi dan kesejahteraan masayarakat desa. Peningkatan kesejahteraan masayarakat merupakan tujuan utama dibentuknya BUMDes, sehingga timbul banyak penelitian yang mempertanyakan peran aktif lembaga ini pada masayarakat desa.

\section{b. Kluster 2}

Kata kunci pada kluster 2 terdiri dari 4 kata kunci yaitu Akuntabilitas, Laporan Keuangan, Tata Kelola, Village Goverment. Kumpulan kata kunci ini mengindikasikan publikasi terkait dengan BUMDes yang berfokus pada pengelolahan BUMDes. Akuntabilitas mewakilkan publikasi terkait dengan pertanggungjelasan pengelolahan BUMDes di Desa terkait. Pertanggungjelasan ini bisa direalisasikan melalui laporan keuangan yang dibuat oleh pengurus BUMDes tersebut.

\section{c. Kluster 3}

Kata kunci pada kluster 3 terdiri dari 3 kata kunci yaitu analisis SWOT, potensi desa, strategi pengembangan. Kumpulan kata kunci ini mengindikasikan publikasi terkait dengan BUMDes dengan bahasan yang berfokus pada tahap pembentukan BUMDes mulai dari identifikasi potensi desa sampai dengan strategi pengembangan yang mumpuni untuk dilakukan.

\section{d. Kluster 4}

Kata kunci pada kluster 4 terdiri dari 1 kata kunci yaitu Community Empowerment atau pemberdayaan masyarakat. BUMDes didirikan untuk kesejahteraan masyarakat, oleh karena itu perlu adanya partisipasi dalam pembangunannya. Inisiatif pemerintah desa untuk menciptakan partisipasi tersebut salah satunya dengan memberdayakan masayarakat.

\section{Tren Topik Akuntansi dan Metode Penelitian dalam Artikel Penelitian Bumdes Setiap Tahun dari Tahun 2015-2020}

Pembagian topik bahasan dalam penelitian BUMDes terkait dengan akuntansi bisa dilihat pada Tabel 11 dan berbagai metode penelitian yang digunakan dalam penelitian tersebut bisa dilihat pada Tabel 12 . 


\section{a. Tren Topik Akuntansi dalam Penelitian Bumdes dari Tahun 2015-2020}

Hasil pembagian topik penelitian akuntansi dalam artikel BUMDes dapat dilihat pada Tabel 11. Pembagian topik penelitian oleh (Coyne et al., 2010b) terdiri dari sistem informasi akuntansi, audit, keuangan, manajemen, dan pajak. Sehingga dari keseluruhan artikel penelitian yang telah terkumpul diklasifikasikan menurut 5 kelompok tersebut. Jika topik artikel bukan merupakan topik akuntansi maka akan diklasifikasikan sebagai topik lain non akuntansi.

Tabel 11. Topik akuntansi dalam penelitian BUMDes dari tahun 2015-2020

\begin{tabular}{|c|c|c|c|c|c|c|c|c|c|c|c|c|c|}
\hline \multirow{2}{*}{ Bidang Akuntansi } & \multicolumn{2}{|c|}{2015} & \multicolumn{2}{|c|}{2016} & \multicolumn{2}{|c|}{2017} & \multicolumn{2}{|c|}{2018} & \multicolumn{2}{|r|}{2019} & \multicolumn{2}{|c|}{2020} & \multirow{2}{*}{ Tota } \\
\hline & $\mathrm{n}$ & $\%$ & $\mathrm{n}$ & $\%$ & $\mathrm{n}$ & $\%$ & $\mathrm{n}$ & $\%$ & $\mathrm{n}$ & $\%$ & $\mathrm{n}$ & $\%$ & \\
\hline $\begin{array}{l}\text { SIA (Sistem Informasi } \\
\text { Akuntansi) }\end{array}$ & - & - & - & - & - & - & 2 & $1,89 \%$ & - & - & - & - & 2 \\
\hline Audit & - & - & - & - & - & - & - & - & 1 & $0,94 \%$ & 1 & $0,94 \%$ & 2 \\
\hline Keuangan & - & - & - & - & - & - & 3 & $2,83 \%$ & 2 & $1,89 \%$ & 3 & $2,83 \%$ & 8 \\
\hline Manajemen & - & - & - & - & - & - & - & - & 4 & $3,77 \%$ & 3 & $2,83 \%$ & 7 \\
\hline Pajak & - & - & - & - & - & - & - & - & - & - & - & - & 0 \\
\hline SIA \& Manajemen & - & - & - & - & - & - & 2 & $1,89 \%$ & - & - & 1 & $0,94 \%$ & 3 \\
\hline Manajemen \& Audit & - & - & - & - & 1 & $0,94 \%$ & - & - & 1 & $0,94 \%$ & - & - & 2 \\
\hline Keuangan \& SIA & - & - & - & - & - & - & - & - & - & - & 1 & $0,94 \%$ & 1 \\
\hline $\begin{array}{l}\text { Topik Lain Non } \\
\text { Akuntansi }\end{array}$ & 2 & $1,89 \%$ & 1 & $0,94 \%$ & 7 & $6,60 \%$ & 16 & $15,09 \%$ & 31 & $29,25 \%$ & 24 & $22,64 \%$ & 81 \\
\hline Sub Total & 2 & $1,89 \%$ & 1 & $0,94 \%$ & 8 & $7,55 \%$ & 23 & $21,70 \%$ & 39 & $36,79 \%$ & 32 & $31,13 \%$ & 105 \\
\hline Total & & & & 106 & & & & & & $100 \%$ & & & \\
\hline
\end{tabular}

Sumber : Data diolah, 2020

Kategori sistem informasi akuntansi digunakan untuk artikel dengan bahasan berkaitan dengan proses pengumpulan, pengelolahan, analisis, dan pengkomunikasian informasi keuangan dalam sistem informasi untuk pengambilan keputusan. Hasil analisis subyek pada Tabel 11 menunjukan bahwa dari tahun 2015 topik sistem informasi akuntansi mulai muncul pada tahun 2018 dengan 2 artikel penelitian (1,89\%). Kedua penelitian ini berfokus pada pemanfaatan sistem informasi sederhana terkait dengan pencatatan keuangan BUMDes sampai dengan pelaporan keuangan. Selanjutnya kategori manajemen ditujukan untuk bahasan terkait dengan perencanaan, penganggaran, serta alokasi sumberdaya yang dimiliki oleh perusahaan dan pengambilan keputusan managerial perusahaan. Hasil analsis pada Tabel 11 dapat diketahui bahwa topik manajemen merupakan topik paling banyak diteliti ke-2 setelah topik keuangan.

Topik manajemen pertama kali muncul dalam penelitian BUMDes pada tahun 2019 dengan 4 artikel penelitian $(3,77 \%)$ dan tahun 2020 terdapat 3 artikel penelitian $(2,83 \%)$. Pada tahun 2019 artikel hasil analsis membahas tentang evaluasi tata kelola, perbaikan standart operasional prosedur terkait dengan aktivitas BUMDes, dan analisis faktor-faktor yang mempengaruhi pengelolahan BUMDes. Hasil penelitian menunjukan fungsi perencanaan dalam BUMDes yang diteliti sudah terlaksana, perencanaan dinilai baik dengan adanya visi misi, formulasi strategi, dan rencana anggaran dalam kegiatannya. Sebagai tambahan untuk topik SIA \& Manajemen dalam Tabel 11 menunjukan bahwa dalam artikel penelitian terdapat dua bahasan sistem informasi akuntansi dan manajemen secara bersamaan. Terdapat 3 artikel dengan dua bahasan topik akuntansi ini yaitu pada tahun 2018 sebanyak 2 artikel (2,83\%) dan terakhir pada tahun 2020 dengan 1 artikel penelitian $(1,89 \%)$.

Klasifikasi artikel dengan topik keuangan dan sistem informasi akuntansi pada Tabel 11 ditujukan bagi artikel penelitian dengan pembahasan mengenai keuangan dan sistem informasi akuntansi secara bersamaan. Pada tahun 2015 sampai dengan 2020 hanya tercatat 1 
artikel dengan 2 bahasan tersebut. Penelitian ini dilakukan oleh (Erlina \& Sirojuzilam, 2020b) dengan tema pengabdian masyarakat terkait dengan teknologi tepat guna. Perbaikan tata kelola keuangan BUMDes dengan pencatatan keuangan dan pelaporan berbasis web. Sehingga pengelolaan keuangan BUMDes lebih efisien, cepat, transparan dan akuntabel ke depannya.

Selanjutnya topik akuntansi audit digunakan mengklasifikasi artikel penelitian dengan bahasan terkait dengan lingkup pemeriksaan keuangan, profesi auditor baik internal maupun external, independensi auditor, fraud, dan bahasan lain terkait dengan auditing. Tercatat hanya terdapat 2 artikel dengan bahasan terkait dengan audit yaitu pada tahun 2019 dan 2020. Hal yang serupa juga terkait dengan topik manajemen dan audit, hanya tercatat 2 artikel dengan 2 topik bahasan tersebut secara bersamaan yaitu pada tahun 2017 dan 2019. Sedangkan untuk topik pajak pada penelitian BUMDes masih belum ada peneliti yang membahas terkait dengan hal tersebut. Metode penelitian lain tercatat dalam Tabel 4.9 merupakan topik diluar ranah akuntansi pada artikel penelitian dengan bahasan BUMDes.

Dari hasil analisis pada Tabel 11 didapatkan informasi terkait dengan tren topik akuntansi dalam publikasi artikel BUMDes. Kecenderungan pemilihan topik akuntansi oleh peneliti pada publikasi ini adalah topik manajemen (2019-2020). Tercatat sebanyak 12 artikel teridentifikasi dengan bahasan manajemen dengan 5 diataranya merupakan artikel dengan 2 topik bahasan akuntansi. Keuangan juga merupakan tren topik penelitian dalam artikel BUMDes pada tahun 2018-2020. Topik keuangan secara konsisten teridentifikasi dalam 3 tahun berturut-turut mulai dari 2018-2020. Topik keuangan juga merupakan topik dengan intensitas tinggi dari topik lain yaitu 9 artikel secara keseluruhan, 1 artikel artikel diantaranya membahas keuangan dan SIA secara bersamaan.

\section{b. Tren Metode Penelitian yang Digunakan dalam Penelitian Bumdes dari Tahun 2015-2020}

Hasil dari ragam metode yang digunakan dalam artikel penelitian BUMDes dapat dilihat pada Tabel 12. Pengelompokan metode penlitian dilakuakan berdasarkan klasifikasi yang dipaparkan oleh (Indriantoro, 2016b). Terbagi menjadi 6 jenis metode penelitian yang biasanya digunakan dalam penelitian bisnis. Penelitian historis, deskriptif, studi kasus dan lapangan, korelasional, kausal komparatif, dan eksperimen. Terdapat 5 metode utama dalam hasil yang teridentifikasi di Tabel 12.

Tabel 12. Metode penelitian artikel BUMDes dari tahun 2015-2020

\begin{tabular}{|c|c|c|c|c|c|c|c|c|c|c|c|c|c|}
\hline \multirow[t]{2}{*}{ Metode Penelitian } & \multicolumn{2}{|c|}{2015} & \multicolumn{2}{|c|}{2016} & \multicolumn{2}{|c|}{2017} & \multicolumn{2}{|c|}{2018} & \multicolumn{2}{|c|}{2019} & \multicolumn{2}{|c|}{2020} & \multirow[t]{2}{*}{ Total } \\
\hline & $\mathrm{n}$ & $\%$ & $\mathrm{n}$ & $\%$ & $\mathrm{n}$ & $\%$ & $\mathrm{n}$ & $\%$ & $\mathrm{n}$ & $\%$ & $\mathrm{~N}$ & $\%$ & \\
\hline \multicolumn{14}{|l|}{ Penelitian Historis } \\
\hline Penelitian Deskriptif & & & & & 1 & $1 \%$ & 1 & $1 \%$ & 5 & $5 \%$ & 7 & $7 \%$ & 14 \\
\hline $\begin{array}{l}\text { Studi Kasus dan } \\
\text { Lapangan }\end{array}$ & & & 1 & $1 \%$ & 6 & $6 \%$ & 17 & $16 \%$ & 30 & $29 \%$ & 21 & $20 \%$ & 75 \\
\hline Penelitian Korelasional & & & & & & & 3 & $3 \%$ & 1 & $1 \%$ & 2 & $2 \%$ & 6 \\
\hline \multicolumn{14}{|l|}{$\begin{array}{l}\text { Penelitian Kausal } \\
\text { Komparatif }\end{array}$} \\
\hline \multicolumn{14}{|l|}{ Penelitian Eksperimen } \\
\hline \multicolumn{14}{|l|}{$\begin{array}{l}\text { Metode Penelitian Lain } \\
\text { (MPL) }\end{array}$} \\
\hline MPL - Conseptual Paper & 2 & $2 \%$ & & & 1 & $1 \%$ & & & 2 & $2 \%$ & 2 & $2 \%$ & 7 \\
\hline MPL - Kajian Literatur & & & & & & & 2 & $2 \%$ & 1 & $1 \%$ & & & 3 \\
\hline Sub Total & 2 & $2 \%$ & 1 & $1 \%$ & 8 & $8 \%$ & 23 & $22 \%$ & 39 & $37 \%$ & 32 & $30 \%$ & 105 \\
\hline Total & & & & 05 & & & & & & $0 \%$ & & & \\
\hline
\end{tabular}


Penelitian historis berkaitan dengan penelitian terhadap masalah-masalah yang berkaitan dengan fenomena masa lalu, dengan tujuan untuk merekonstruksi peristiwa yang sudah pernah terjadi pada masa lalu dan menjelaskan mengapa peristiwa itu dapat terjadi. Dari hasil identifikasi metode penelitian dalam artikel BUMDes belum ditemukan penelitian dengan metode ini. Sedangkan untuk penelitian deskriptif dimaksutkan untuk penelitian penelitian terhadap masalah-masalah berupa fakta saat ini dari suatu populasi, secara umum penelitian ini bertujuan untuk menggambarkan, memvalidasi, dan menjelaskan fenomena sosial yang menjadi subyek penelitian kualitatif maupun kuantitatif.

Hasil identifikasi pada Tabel 12 menunjukan bahwa sebanyak 14 artikel penelitian menggunakan metode deskriptif atau sebesar 13,3\% dari kesuluran artkel yang dianalisis. Artikel penelitian dengan metode ini didominasi oleh bahasan pokok terkait dengan peran didirikanya BUMDes dalam suatu wilayah tertentu, persepsi masyarakat dan pemerintah dalam pendiriannya, dan ada juga berkaitan dengan strategi pengembangan BUMDes dalam lingkup kabupaten. Penelitian dengan metode studi kasus dan lapangan merupakan metode yang yang paling banyak digunakan dalam artikel penelitian BUMDes. Hasil dari analisis pada Tabel 12 menunjukkan bahwa $75(71,4 \%)$ artikel dari 105 artikel merupakan studi kasus dan lapangan. Penelitian dengan metode ini paling banyak digunakan pada tahun 2019 dengan 30 (29\%) artikel penelitian. Klasifikasi studi kasus dan lapangan dimaksutkan untuk artikel dengan metode penlitian terkait dengan latar belakang dan kondisi saat ini dari suatu subyek yang diteliti, serta interaksinya dengan lingkungan. Subyek penelitian bisa berupa individu, kelompok, ataupun suatu lembaga dengan tujuan penyelidikan secara mendalam untuk menghasilkan gambaran yang lengkap dari subyek yang diteliti. Menggunakan skema studi kasus menurut peneliti merupakan metode yang relatif sesuai untuk digunakan pada peneitian di bidang BUMDes. Hal tersebut karena ciri khas, potensi, dan masalah setiap BUMDes sangat beragam, sehingga dengan penelitian studi kasus bisa lebih menghasilkan pemahaman yang mendalam terkait dengan BUMDes yang diteliti.

Klasifikasi penelitian korelasional dimaksutkan pada jenis penelitian dengan karakteristik masalah berupa hubungan korelasional antara dua variabel atau lebih. Tujuan penelitian ini adalah untuk mengetahui ada atau tidaknya hubungan korelasi antar variabel atau membuat prediksi berdasarkan korelasi antar variabel. Dari hasil analisis terdapat 6 $(5,7 \%)$ artikel penelitian yang menggunakan metode korelasional Sedangkan untuk klasifikasi penelitian kausal komparatif dan penelitian eksperimen pada artikel penelitian dengan bahasan BUMDes belum pernah dilakukan.

Metode penlitian lain hasil analisis sesuai dengan Tabel 12 hanya terdapat 2 metode yaitu kajian literatur dan jenis artikel conseptual paper. Kajian literatur merupakan penelitian yang menelaah, meninjau atau mengkaji secara kritis suatu pengetahuan, gagasan, ide atau temuan yang terdapat dalam suatu literatur dengan berorientasi akademik. Kajian literatur tercatat hanya terdapat dua artikel pada tahun 2018, dan conseptual paper tercatat hanya 7 artikel dari tahun 2015-2020.

Berdasarkan hasil dari analisis pada Tabel 12 diperoleh gambaran tren metode penlitian yang digunakan pada artikel penelitian ini. Metode studi kasus dan lapangan merupakan tren metode penelitian dalam artikel BUMDes. Teridentifikasi sebesar 71,42 \% artikel penelitian BUMDes yang dianalisis menggunakan skema studi kasus. Kecenderungan penggunaan metode studi kasus dan lapangan pada penelitian ini didasarkan pada ciri khas dan permasalah masing masing BUMDes. Sehingga dengan menggunakan metode ini dinilai lebih efektif untuk melakuakn identifikasi, atau pemecahan masalah yang ada. 


\section{Potensi Penelitian Selanjutnya}

Rekomendasi untuk penelitian selanjutnya yaitu dapat secara aktif melakukan kajian ilmiah terhadap kebutuhan tata kelola BUMDes yang lebih efektif. Hal hal ini karena keterbatasan sumberdaya yang dimiliki oleh BUMDes, sehingga dengan kajian ilmiah yang dilakukan secara tidak langsung dapat menutupi kendala tersebut. Topik bahasan terkait dengan keuangan serta auditing juga merupakan pilihan yang direkomendasikan karena sejalan dengan (Zulbetti et al., 2019) bahwa literasi keuangan pengurus bumdes dinilai masih dibawah rata-rata. Penyalagunaan wewenang juga memiliki potensi besar dalam pengelolahan BUMDes, khususnya kepala desa yang berperan sebagai penasihat dan mempunyai kedudukan tertinggi di desa (Firdaus, 2018). Hal ini menjadikan kebutuhan terhadap penelitian terhadap kepatuhan dalam pengelolahan BUMDes menjadi perlu.

\section{KESIMPULAN}

Berdasarkan hasil dan pembahasan di atas dapat disimpulkan bahwa pertumbuhan publikasi artikel ilmiah dengan bahasan BUMDes terjadi peningkatan secara signifikan mulai dari tahun 2017 sampai 2019. Publikasi BUMDes tertinggi terjadi pada tahun 2019 sebanyak 90 artikel (40\%). Intitusi paling produktif dalam penelitian ini adalah Universitas Pendidikan Ganesha, dan jurnal ilmiah yang paling banyak mempublikasikan penelitian BUMDes adalah Jurnal Ilmiah Akuntansi dan Humanika. Tingkat produktifitas penulis tidak menunjukkan adanya penulis dengan kontribusi yang signifikan dari jumlah hasil tulisannya. Rata-rata kontribusi dari masing masing penulis dalam penelitian ini berkisar 2 sampai 3 artikel penelitian.

Topik paling banyak diteliti adalah tentang kesejahteraan masyarakat desa dan ekonomi desa berkaitan dengan peran aktif keberadaan BUMDes didalamnya. Hal tersebut mengindikasikan bahwa penelitian ini masih berfokus pada lingkup penelitian sosial, lain hal dengan fokus penelitian dengan topik akuntansi berfokus pada bahasan keuangan dan manajemen pengelolahan BUMDes. Masalah utama pengelolahan BUMDes yang terdapat pada sumberdaya manusia yang sebagian besar hanya terbatas pada masayarakat desa yang belum tentu memiliki keterampilan yang memadai terkait dengan pengelolahan BUMDes. Hal tersebut membuat topik terkait pertangungjawaban dan pelaporan keuangan BUMDes menjadi hal paling sering diteliti. Skema studi kasus dan lapangan manjadi kecendrungan metode penelitian yang dipakai, karena ciri khas dan permasalahan masing-masing BUMDes berbeda. Berdasarkan hal tersbut penggunaan metode ini dinilai lebih efektif untuk melakukan identifikasi, atau pemecahan masalah yang ada. Kebutuhan terkait dengan ketentuan monitoring dan evaluasi sumberdaya manusia membuat celah kebutuhan penelitian selanjutnya. Kajian ilmiah terhadap kebutuhan tata kelola BUMDes yang lebih efektif menjadi potensi penelitian agar keterbatasan sumberdaya dapat diatasi dengan tata kelola yang mumpuni.

\section{REFERENSI}

Basuki, S. (2002). Pemetaan Ilmu Pengetahuan. Kumpulan Makalah Kursus Bibliometrika.

Coyne, J. G., Summers, S. L., Williams, B., \& Wood, D. A. (2010a). Accounting program research rankings by topical area and methodology. Issues in Accounting Education, 25(4), 631-654. https://doi.org/10.2308/iace.2010.25.4.631

Coyne, J. G., Summers, S. L., Williams, B., \& Wood, D. A. (2010b). Accounting program research rankings by topical area and methodology. Issues in Accounting Education, 25(4), 631-654. https://doi.org/10.2308/iace.2010.25.4.631 
Erlina, E., \& Sirojuzilam, S. (2020a). Efektivitas Penerapan Sistem Pencatatan Dan Pelaporan Keuangan Bumdes Sistem Akuntansi Bumdes Berbasis Web. Owner, 4(1), 282. https://doi.org/10.33395/owner.v4i1.195

Erlina, E., \& Sirojuzilam, S. (2020b). Efektivitas Penerapan Sistem Pencatatan Dan Pelaporan Keuangan Bumdes Sistem Akuntansi Bumdes Berbasis Web. Owner, 4(1), 282. https://doi.org/10.33395/owner.v4i1.195

Farida, N., \& Firmansyah, A. H. (2020a). Analisis Bibliometrik Berdasarkan Pendekatan Co-Word: Kecenderungan Penelitian Kearsipan di Jurnal Khazanah: Jurnal Pengembangan Kearsipan dan Journal of The Archives and Records Association, Tahun 2016-2019. Khazanah: Jurnal Pengembangan Kearsipan., 13(2), 91-109.

Farida, N., \& Firmansyah, A. H. (2020b). Analisis Bibliometrik Berdasarkan Pendekatan Co-Word: Kecenderungan Penelitian Kearsipan di Jurnal Khazanah: Jurnal Pengembangan Kearsipan dan Journal of The Archives and Records Association, Tahun 2016-2019. Khazanah: Jurnal Pengembangan Kearsipan., 13(2), 91-109.

Firdaus, S. (2018). FENOMENA ELITE CAPTURE DALAM PENGELOLAAN BADAN USAHA MILIK DESA (BUMDES). Politika: Jurnal Ilmu Politik, 9(2), 20. https://doi.org/10.14710/politika.9.2.2018.20-37

Hakim, L. (2020). Procuratio: Jurnal Ilmiah Manajemen BIBLIOGRAPHY ANALYSIS OF BUSINESS INCUBATOR RESEARCH IN SCIENTIFIC. 8(2).

Indriantoro, N. (2016a). Metodologi Penelitian (I). BPFE-Yogyakarta.

Indriantoro, N. (2016b). Metodologi Penelitian (I). BPFE-Yogyakarta.

Maulana, R. R. (2014). Penerapan Otonomi Daerah Dalam Pembangunan Desa Application of Regional Autonomy in Village Development. 1-4.

Pradesa, H. A., \& Agustina, I. (2020). Implementasi Konsep Tanggung Jawab Sosial sebagai Upaya Meningkatkan Efektivitas Pengelolaan BUMDes. JURNAL MANAJEMEN DAN KEWIRAUSAHAAN, 8(2). https://doi.org/10.26905/jmdk.v8i2.4768

Purnomo, A. (2019). Manfaat Penelitian Bibliometrik untuk Indonesia dan Internasional. 1-2. https://doi.org/10.31227/osf.io/f2xg7

Rachmawati, R., Data, P., \& Lipi, I. (2020). TREN PENELITIAN STRUKTUR TEKTONIK INDONESIA 2001-2020 : SEBUAH PENDEKATAN BIBLIOMETRIK. 22(2).

Ridlwan, Z. (2015a). Payung Hukum Pembentukan BUMDes. FIAT JUSTISIA:Jurnal Ilmu Hukum, 7(3). https://doi.org/10.25041/fiatjustisia.v7no3.396

Ridlwan, Z. (2015b). Payung Hukum Pembentukan BUMDes. FIAT JUSTISIA:Jurnal Ilmu Hukum, 7(3). https://doi.org/10.25041/fiatjustisia.v7no3.396

Ridlwan, Z. (2015c). Urgensi Badan Usaha Milik Desa (Bumdes) Dalam Pembangun Perekonomian Desa. FIAT JUSTISIA:Jurnal Ilmu Hukum, 8(3), 424-440. https://doi.org/10.25041/fiatjustisia.v8no3.314

Ridlwan, Z. (2015d). URGENSI BADAN USAHA MILIK DESA (BUMDES) DALAM PEMBANGUN PEREKONOMIAN DESA. FIAT JUSTISIA:Jurnal Ilmu Hukum, 8(3). https://doi.org/10.25041/fiatjustisia.v8no3.314 
Rika Fatimah, P. (2019). Mengembangkan Kualitas Usaha Milik Desa (Q-BUMDes) untuk Melestarikan Ketahanan Ekonomi Masyarakat dan Kesejahteraan Adaptif: Perancangan Sistem Kewirausahaan Desa dengan Menggunakan Model Tetrapreneur. Jurnal Studi Pemuda, 7(2), 122. https://doi.org/10.22146/studipemudaugm.39551

Sufi, W., \& Saputra, T. (2017). Implementation of village empower program in supporting form of institutions of village business institutions (BUMDes) (Study on Dayang Suri Village Bungaraya Sub District Siak Regency Riau Province). Jurnal Perspektif Pembiayaan Dan Pembangunan Daerah, 5(2), 91-98. https://doi.org/10.22437/ppd.v5i2.4420

Sulaksana, J., \& Nuryanti, I. (2019). Strategi Pengembangan Badan Usaha Milik Desa (Bumdes) Kasus Di Bumdes Mitra Sejahtera Desa Cibunut Kecamatan Argapura Kabupaten Majalengka. Jurnal Ekonomi Pertanian Dan Agribisnis, 3(2), 348-359. https://doi.org/10.21776/ub.jepa.2019.003.02.11

Surono, A. (2017). Peranan Hukum Dalam Pengelolaan Sumber Daya Alam Skala Desa Oleh Badan Usaha Milik Desa (Bumdes) Dalam Meningkatkan Kesejahteraan Masyarakat Desa. Jurnal Rechts Vinding: Media Pembinaan Hukum Nasional, 6(3), 459. https://doi.org/10.33331/rechtsvinding.v6i3.195

Tupan, \& Rachmawati, R. (2018). Analisis Bibliometrik Ilmu dan Teknologi Pangan: Publikasi Ilmiah dI Negara-Negara ASEAN. Khizanah Al-Hikmah : Jurnal Ilmu Perpustakaan, Informasi, Dan Kearsipan, 6(1), 26-40. https://doi.org/10.24252/kah.v6i1a4

Utama, A. A. G. S., Hikmawati, E. E., Herwiyanti, E., \& Fatmah, F. (2019). Evaluasi dan Pengembangan Sistem BUMDes Wisata Kemiren Berbasis Web Studi Kasus www.kemiren.com. Ekuitas: Jurnal Pendidikan Ekonomi, 33. https://doi.org/10.23887/ekuitas.v7i1.16731

Zulbetti, R., Perwito, P., \& Puspita, V. A. (2019). Upaya Peningkatan Literasi Keuangan Pengurus BUMDES Melalui Pelatihan Keuangan di Kecamatan Cimaung Kabupaten Bandung. Ekonomikawan: Jurnal Ilmu Ekonomi Dan Studi Pembangunan, 19(2), 200-211. https://doi.org/10.30596/ekonomikawan.v19i2.3824

Zulyanto, D., Herdiansyah, D., \& Elida, S. S. (2017). SKENARIO PEMBIAYAAN MIKRO BUMDes BERBASIS POTENSI ELIT DESA SUNGAI KAKAP KABUPATEN KUBU RAYA. Inovbiz: Jurnal Inovasi Bisnis, 5(2), 167. https://doi.org/10.35314/inovbiz.v5i2.253 